\title{
HUBUNGAN PRAKTIK KERJA INDUSTRI DENGAN KESIAPAN KERJA SISWA SMK NEGERI 1 CIBINONG KELAS XII KOMPETENSI KEAHLIAN TEKNIK GAMBAR BANGUNAN
}

\author{
Yudiana Pratama ${ }^{1}$, Daryati', Riyan Arthur ${ }^{3}$ \\ ${ }^{1}$ Alumni PTB FT UNJ, yudiyana18@gmail.com \\ 2Dosen PTB FT UNJ, daryati sr@uni.ac.id \\ 3Dosen PTB FT UNJ, arthur@unj.ac.id
}

\begin{abstract}
Abstrak
Tujuan Penelitian untuk mengetahui hubungan antara praktik kerja industri terhadap kesiapan kerja siswa di Kompetensi Keahlian Teknik Gambar Bangunan SMK Negeri 1 Cibinong, yang beralamat di Jalan Karadenan No.7, Cibinong Bogor, Jawa Barat16913. Penelitian ini dilaksanakan selama 4 bulan sejak Oktober 2017 sampai dengan Januari 2018 yang teridir dari tiga tahap yaitu tahap persiapan, tahap pelaksanaan, dan tahap pengolahan data.

Jenis penelitian yang digunakan adalah kuantitatif asosiatif. Metode penelitian adalah metode survei dengan pendekatan korelasi. Populasi adalah siswa SMK Negeri 1 Cibinong Kompetensi Keahlian Teknik Gambar Bangunan yaitu sebanyak 212 orang siswa. Sampel menggunakan cluster random sampling, yang akan dilakukan pada siswa kelas XII sebanyak 69 orang siswa, yaitu kelas XII TGB 1,yang berjumlah 35 siswa, kelas XII TGB 2, yang berjumlah 34 siswa.

Hasil penelitian adalah nilai koefisien korelasi sebesar 0,41 dengan kategori sedang, dan terdapat hubungan yang signifikan dari praktik kerja industri terhadap kesiapan kerja siswa di SMK Negeri 1 Cibinong Kompetensi Keahlian Teknik Gambar Bangunan. Penelitian ini dibuktikan dengan $\mathrm{t}_{\text {hitung }}$ lebih besar dari $\mathrm{t}_{\text {tabel }}$ sebesar 3,644 > 1,66 para taraf signifikan 5\% maka $\mathrm{H}_{0}$ ditolak dan $\mathrm{H}_{1}$ diterima.
\end{abstract}

Kata Kunci : Praktik Kerja Industri, Kesiapan Kerja

\section{RELATIONSHIP OF INDUSTRIAL WORK PRACTICES WITH STUDENT PREPARATION STUDENT SMK NEGERI 1 CIBINONG CLASS XII COMPETENCY SKILLS TECHNIQUE DRAWINGS BUILDING}

\author{
Yudiana Pratama ${ }^{1}$, Daryati', Riyan Arthur \\ 'Alumni PTB FT UNJ,yudiyana18@,gmail.com \\ ${ }^{2}$ Lecturer of PTB FT UNJ, daryatisn@unj.ac.id \\ ${ }^{3}$ Lecturer of PTB FT UNJ, arthur@unj.ac.id
}

Abstract

The purpose of research to know the relationship between work practices against best work inside the box making is a sunset industry readiness to administer the program cbild in that school in competency skills gambar bangunan explained that well as those from vocational 1 cibinong, lived at jl karadenan no.7, cibinong bogor jawa barat he said, jawa barat16913. This research has been conducted for 4 months have passed since the october 2017 to january 2018 which consists of three stages of preparation stage, implementation phase, and processing phase. 
The kind of research that is used is identification quantitative associative. Research methodology is a method of surveying the with the approach at least a high school.Percent of the population was students graduate well as those from vocational 1 cibinong competency of building explained that with the rest of teachers 212 of people students. A small sample of using clusters of random sampling, who will be conducted in student of class xii as many as 69 of people students, pt pgn promised to supply of class XII TGB 1 , that the others were twice 35 students, of class XII TGB 2, that the others were twice 34 students.

The results of the study is the value of a correlation coefficient Of 0,41 with medium category, and there are a significant realation form practices industrial work against readiness work students in state vocational schools 1

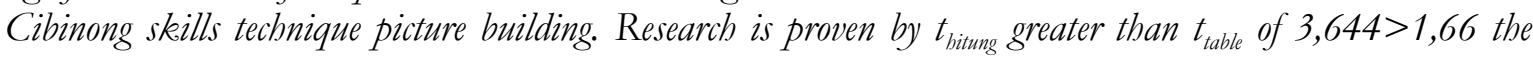
level of significant so $\mathrm{H}_{0} 5 \%$ were rejected and $\mathrm{H}_{1}$ accepted.

Keywords: Industrial Work Practices, Readiness Work

\section{Pendahuluan}

Sumber daya manusia (SDM) merupakan salah satu faktor kunci dalam reformasi ekonomi. Bagaimana menciptakan SDM yang berkualitas dan memiliki keterampilan serta berdaya saing tinggi dalam persaingan global yang selama ini diabaikan. Maka dari itu pemerintah melakukan berbagai cara untuk meningkatkan kualitas sumber daya manusia tersebut baik dalam pendidikan formal maupun informal. Perkembangan ilmu pengetahuan dan teknologi serta tuntutan globalisasi secara bersama-sama telah mengakibatkan persaingan yang semakin ketat dalam penyediaan sumber daya manusia yang unggul. Untuk terus dapat mempertahankan daya saingnya, sumber daya manusia yang ada dituntut untuk terus meningkatkan pengetahuan, keterampilan, sikap dan kompetensinya. Tingkat kompetensi yang tinggi, seseorang akan cepat menyesuaikan perubahan yang di sekitarnya, termasuk dalam pekerjaan, maupun dalam berorganisasi.

SMK dibentuk untuk menyiapkan peserta didik atau lulusan yang siap memasuki dunia kerja dan mampu mengembangkan sikap profesional dibidang kejuruan. Lulusan pendidikan kejuruan diharapkan menjadi individu yang produktif yang mampu bekerja menjadi tenaga kerja dan memiliki kesiapan untuk menghadapi persaingan kerja. Lulusan SMK diharapkan memiliki kesiapan kerja yang baik guna mewujudkan pendidikan SMK, hal ini didukung dikeluarkannya kebijakan pemerintah dengan memperbanyak jumlah SMK.

Sekolah Menengah Kejuruan (SMK) merupakan lembaga pendidikan yang bertujuan menyiapkan peserta didiknya mempunyai pengetahuan, keterampilan, dan sikap kerja yang sesuai dengan kebutuhan lapangan pekerjaan. Serta menjadikan tenaga kerja yang terampil dan mengutamakan kemampuan untuk meleksanakan pekerjaan tertentu. SMK diharapkan mampu menghasilkan lulusan yang mampu bekerja secara produktif, memiliki kemampuan, keterampilan dan siap kerja. Kenyataannya sebagian besar Sekolah Menengah Kejuruan saat ini belum bisa sepenuhnya memenuhi permintaan kompetensi dunia usaha maupun dunia industri. Harapan tersebut ternyata belum dapat terpenuhi sebagaimana mestinya, tingkat keterampilan, motivasi dan kurangnya kesiapan kerja yang dimiliki para lulusan SMK ternyata masih lemah. Terjadinya kesenjangan antara lulusan dengan dunia kerja yang terlihat dengan terus meningkatnya jumlah pengangguran. Banyak lulusan SMK yang bekerja di bidang yang tidak sesuai dengan kompetensi keahliannya yang dipelajari di sekolah.

Sesuai dengan Misi Sekolah Menengah Kejuruan (SMK) yaitu mempersiapkan peserta didik sebagai calon tenaga kerja yang memiliki kesiapan untuk memasuki dunia kerja. Keberadaan SMK dituntut untuk memenuhi kebutuhan dunia kerja. SMK sebagai institusi yang 
mempersiapkan peserta didik untuk mampu terjun langsung ke dunia kerja setelah lulus serta mencetak tenaga terampil diberbagai bidang keahlian sebagai pemenuhan kompetensi disegala bidang. Dengan demikian peserta didik dituntut untuk memiliki keterampilan dan sikap profesional dalam bidangnya. Pelaku tenaga kerja harus mempersiapkan dirinya sebaik mungkin. Kesiapan merupakan hal yang sangat penting yang harus dimiliki oleh calon tenaga kerja. Oleh karena itu peserta didik harus benar-benar siap dalam menghadapi dunia kerja ketika lulus nanti. Dalam mempersiapkan peserta didik yang memiliki kesiapan kerja yang baik.

Praktik kerja industri adalah
program wajib tempuh yang
diselenggarakan oleh sekolah khususnya sekolah menengah kejuruan (SMK), yang wajib diikuti oleh peserta didik/kelompok belajar. Penyelenggaraan praktik kerja industri akan membantu peserta didik untuk memantapkan hasil belajar yang diperoleh di sekolah serta membekali peserta didik dengan pengalaman nyata sesuai dengan program studi yang dipilihnya.(Dikmenjur, 2013: 10). Praktik kerja industri juga merupakan bentuk latihan nyata yang dilakukan oleh peserta didik agar bisa beradaptasi dengan dunia kerja, agar setelah lulus dari sekolah nanti peserta didik diharapkan tidak kaget dan bisa cepat menyesuaikan diri dengan lingkungan kerja. Serta menambah wawasan pengetahuan dan pengalaman dalam bekerja.

Kesiapan kerja adalah suatu kemampuan yang dimiliki oleh peserta didik untuk dapat langsung bekerja setelah lulus dari SMK, yang meliputi kematangan fisik, kematangan mental, serta pengalaman yang didapat. Kesiapan siswa dalam memasuki dunia kerja dipengaruhi oleh faktor internal dan eksternal. Faktor internal yaitu mencakup pengetahuan, keterampilan dan kesiapan mental yang dimiliki oleh siswa itu sendiri sesuai dengan kompetensi keahliannya masing-masing. Sedangkan faktor eksternal yaitu mencakup dari luar diri siswa, meliputi peran sarana dan prasarana sekolah, keluarga, masyarakat, informasi dunia kerja, serta pengalaman kerja. Jadi kesiapan kerja merupakan suatu keadaan yang menunjukkan seseorang itu telah siap untuk menggunakan kemampuannya dalam melaksanakan suatu kegiatan, serta kesiapan kerja diperlukan untuk mencetak calon tenaga kerja yang tangguh dan berkualitas.

Berdasarkan dokumen hasil penelusuran tamatan SMK Negeri 1 Cibinong di jurusan keahlian teknik gambar bangunan pada tahun 2016/2017, gejala yang terjadi pada kesiapan kerja siswa kelas XII sebanyak 72 peserta didik telah berhasil lulus dari sekolah tersebut. Akan tetapi dari jumlah tersebut hanya 10 orang siswa bekerja setelah lulus, sebanyak 41 orang melanjutkan pendidikannya kejenjang yang lebih tinggi, 21 orang belum mendapatkan pekerjaan. Dari sekian banyaknya lulusan peserta didik, SMK Negeri 1 Cibinong hanya mampu memberikan lulusan peserta didiknya sebanyak 10 orang, mereka langsung bekerja setelah lulus dari sekolah tersebut, yaitu sebanyak 5 orang di PT. Catur Griya Naradipa, yang bergerak dibidang interior kontraktor, sebanyak 3 orang di PT. YW Arsitektur Cibinong, yang bergerak dibidang Arsitek dan sebanyak 2 orang di PT. Totalindo, yang bergerak dibidang jasa konstruksi.

Kesiapan siswa dalam memasuki dunia kerja dipengaruhi oleh faktor internal dan eksternal, faktor internal diantaranya pengetahuan, keterampilan, dan kesiapan mental yang dimiliki oleh siswa itu sendiri sesuai dengan kompetensi keahliannya masing-masing. Siswa yang mengambil kompetensi keahlian teknik gambar bangunan diharapkan dapat menguasai segala pengetahuan yang telah disampaikan dalam kegiatan belajar mengajar disekolah sehingga siswa mampu memiliki kompetensi sesuai dengan kompetensi 
keahliannya. Faktor eksternal yang mempengaruhi kesiapan kerja siswa dalam hal ini adalah praktik kerja industri.

Berdasarkan data yang diperoleh dari hasil observasi pada bulan Oktober 2017 pada 69 peserta didik, yang telah melaksanakan praktik kerja industri kurang dapat memberikan hasil yang maksimal bagi peserta didik, hal ini terlihat peserta didik tidak dapat menerapkan keterampilan yang diperoleh di sekolah ke dunia industri, karena kompetensi yang dimiliki kurang sesuai dengan dunia industri. Peserta didik kurang memahami penggunaan alat-alat yang ada di tempat praktik kerja industri, dan tidak bertanya kepada pembimbing dilapangan tentang cara menggunakannya, siswa selama praktik kerja industri hanya mendapatkan pengalaman sedikit karena kurangnya komunikasi antara praktikan dengan karyawannya. Selain itu dalam pelaksanaan program praktik kerja industri terbukti bahwa masih ada ditemukan adanya penyimpangan dalam hal pemberian tugas dan kurangnya pemberian kepercayaan kepada siswa dan keterampilan serta mental siswa yang dinilai kurang oleh institusi pasangan, tidak sedikit dari institusi pasangan yang hanya memanfaatkan siswa praktik kerja industri tanpa memberikan masukan ataupun feedback yang mampu mendongkrak kemampuan kinerja siswa. Selanjutnya ditemukan data nilai praktik kerja industri siswa kelas XII SMK Negeri 1 Cibinong Kompetensi Keahlian Teknik Gambar Bangunan pada tahun 2016/2017 semester ganjil, ditemukan rata-rata nilai praktik kerja industri masih ada 34\% siswa di bawah rata-rata. (Lihat lampiran $1 \mathrm{Hal}$. 57).

Pendidikan kejuruan yang sepenuhnya diselenggarakan oleh sekolah kurang mampu menyesuaikan diri dengan perubahan dan perkembangan dunia kerja, sehingga kesiapan kerja peserta didik menjadi kurang. Dengan demikian permasalahan pendidikan SMK yang di rasakan saat ini adalah ketidak siapan lulusannya memasuki dunia kerja.

Mencermati permasalahan tersebut, sangat penting untuk dilakukan penelitian mengenai hubungan praktik kerja industri dengan kesiapan kerja siswa SMK Negeri 1 Cibinong kelas XII Kompetensi Keahlian Teknik Gambar Bangunan. Hal tersebut agar dari program praktik kerja industri diperoleh peserta didik yang memiliki kematangan dan kesiapan dalam menghadapi persaingan dunia kerja.

\section{Identifikasi Masalah}

Berdasarkan pada latar belakang masalah yang telah diuraikan, maka dapat diidentifikasi masalah sebagai berikut:

1. Apa hal yang mempengaruhi tingginya tingkat pengangguran pada lulusan SMK?

2. Mengapa praktik kerja industri tidak berpengaruh secara maksimal kepada siswa?

3. Faktor internal dan faktor eksternal apa sajakah yang mempengaruhi kesiapan kerja siswa?

4. Mengapa masih rendahnya lulusan SMK yang terserap di lapangan kerja?

5. Apakah terdapat hubungan antara praktik kerja industri dengan kesiapan kerja siswa?

\section{Batasan Masalah}

Berdasarkan permasalahan yang dihadapi, maka untuk memfokuskan pemecahan masalah, peneliti akan membatasi pada permasalahan sebagai berikut yaitu:

1. Hubungan antara praktik kerja industri dengan kesiapan kerja siswa

2. SMK Negeri 1 Cibinong

3. Siswa kelas XII Kompetensi Keahlian Teknik Gambar Bangunan

4. Praktik Kerja Industri

5. Kesiapan Kerja Siswa 


\section{Rumusan Masalah}

Berdasarkan identifikasi masalah di atas, maka dapat dirumuskan masalah sebagai berikut: Apakah terdapat hubungan praktik kerja industri dengan kesiapan kerja siswa SMK Negeri 1 Cibinong Kompetensi Keahlian Teknik Gambar Bangunan?

\section{Tujuan Penelitian}

Berdasarkan rumusan masalah di atas, maka tujuan penelitian ini adalah untukmengetahui adanya hubungan paktik kerja industri dengan kesiapan kerja siswa SMK Negeri 1 Cibinong kelas XII Kompetensi Keahlian Teknik Gambar Bangunan.

\section{Manfaat Penelitian}

Adapun manfaat teoritik dari penilitian ini :

1. Dapat memberi sumbangan informasi bagi penelitian berikutnya.

2. Dapat menambah ilmu pengetahuan secara umum khususnya ilmu kejuruan

Sedangkan manfaat praktis :

1. Sebagai bahan pertimbangan pengambilan kebijakan dalam mengembangkan program praktik kerja industri pengetahuan tentang dunia kerja kepada peserta didik.

2. Sebagi salah satu wahana dalam penerapan teori-teori yang diperoleh selama menjalani studi di Program Studi S1 Pendidikan Teknik Bangunan

\section{Tinjauan Pustaka}

1. Kesiapan Kerja Siswa SMK

Menurut Wibowo (2011 : 324) kesiapan kerja adalah "Suatu kemampuan seseorang untuk melaksanakan atau melakukan suatu pekerjaan atau tugas yang dilandasi keterampilan dan pengetahuan yang dicirikan oleh profesionalisme serta didukung oleh sikap kerja yang dituntut oleh pekerjaan tersebut".

Selanjutnya menurut Dalyono (2005: 52) kesiapan kerja adalah "Kemampuan yang cukup baik bagi fisik dan mental. Kesiapan fisik berarti tenaga yang cukup dan kesehatan yang baik, sementara kesiapan mental memiliki minat dan motivasi yang cukup untuk melakukan suatu kegiatan"

Menurut Sugihartono (2000:15) kesiapan kerja adalah "Kondisi yang menunjukkan adanya keserasian antara kematangan fisik, kematangan mental, dan pengalaman belajar sehingga individu mempunyai kemampuan untuk melaksanakan suatu kegiatan atau tingkah laku tertentu dalam hubungannya dengan pekerjaan".

Berdasarakan para ahli di atas dapat disimpulkan bahwa kesiapan kerja yaitu suatu kondisi dimana seseorang dinyatakan siap secara kemampuan yang dimiliki oleh dirinya sendiri, serta adanya kemauan dan kemampuan siswa untuk langsung terjun ke dunia kerja setelah lulus dari sekolah. Tanpa harus membutuhkan waktu dan penyesuaian yang lama di lingkungan kerja, dengan didukung oleh kematangan mental, fisik dan pengalaman belajar yang harus dimiliki oleh peserta didik untuk mencapai tujuan tertentu sesuai kebutuhan dunia kerja

Dalam Undang-Undang RI N0.20 Tahun 2003 Pasal 1 Tentang Sistem Pendidikan Nasional, tujuan khusus pendidikan kejuruan sebagi berikut :

1. Menyiapkan peserta didik agar menjadi manusia produktif, mampu bekerja mandiri, mengisi lowongan pekerjaan yang ada di dunia usaha maupun dunia industri sebagai tenaga kerja tingkat menengah, sesuai dengan kompetensi 
dalam program keahlian yang dipilihnya.

2. Menyiapkan peserta didik agar mampu memilih karir, ulet dan gigih dalam berkompetensi, beradaptasi di lingkungan kerja, dan mengembangkan sikap professional dalam bidang keahlian yang diminatinya.

3. Membekali peserta didik dengan ilmu pengetahuan, teknologi, dan seni, agar mampu mengembangkan diri dikemudian hari baik secara mandiri maupun melalui jenjang pendidikan yang lebih tinggi.

4. Membekali peserta didik dengan kompetensi-kompetensi sesuai dengan program keahliannya.

Penjelasan di atas, terlihat bahwa sekolah kejuruan adalah sekolah yang mempersiapkan lulusan yang benar-benar mempunyai kesiapan kerja yang matang. Kesiapan kerja siswa SMK merupakan kemampuan yang harus dimiliki oleh siswa untuk dapat langsung bekerja setelah lulus dari sekolah. Kesiapan kerja merupakan modal utama bagi siswa untuk melakukan pekerjaan, sehingga dengan kesiapan kerja akan diperoleh hasil yang maksimal. Jadi kesiapan kerja sangatlah penting bagi siswa SMK, karena tuntutan dunia kerja akan penguasaan sejumlah kompetensi kerja yang sangat dibutuhkan.

\section{Praktik Kerja Industri}

Menurut Wibowo menjelaskan bahwa praktik kerja industri "Merupakan bentuk kerja sama antara SMK dengan industri yang selama ini dilakukan oleh sekolah-sekolah dengan memberikan kepercayaan terhadap industri untuk membimbing siswa mencapai kompetensi sesuai sesuai dengan kurikulum".

Sedangkan menurut Iriani dan Soeharto (2015:276) bahwa praktik kerja industri adalah "Praktik kerja industri yaitu program wajib yang harus diselenggarakan oleh sekolah khusunya SMK dan pendidikan luar sekolah serta wajib diikuti oleh siswa/warga belajar. Kegiatan praktik kerja industri membantu peserta didik untuk menerapkan hasil belajar yang di perolah di sekolah serta sebagai sarana bagi siswa untuk memperoleh pengalaman nyata bekerja sesuai dengan kondisi sesungguhnya".

Beberapa pendapat para ahli di atas, dapat disimpulkan bahwa praktik kerja industri adalah program wajib yang dilaksanakan oleh sekolah khususnya SMK. Kegiatan praktik kerja industri membantu peserta didik untuk menerapkan hasil belajar yang diperoleh di sekolah, serta memperoleh pengalaman dan pengetahuan kepada peserta didiknya sesuai dengan kompetensinya keahliannya masing-masing. Praktik kerja industri harus bisa menghasilkan lulusan peserta didiknya yang berkompeten sehingga mampu bersaing dengan pekerja yang bukan merupakan lulusan SMK.

Selanjutnya pendapat yang disampaikan oleh Hamalik (2005:91) menjelaskan tentang praktik kerja industri adalah"Praktik kerja industri merupakan suatu tahap persiapan profesional dimana seorang siswa yang hampir menyelesaikan studi secara formal bekerja di lapangan dengan suvervisi seorang administrator yang kompeten dalam jangka waktu tertentu, yang bertujuan untuk mengembangkan kemampuan untuk melaksanakan tanggung jawab dalam bidangnya”.

Menurut kurikulum SMK (Dikmenjur, 2013) menyebutkan bahwa praktik kerja industri adalah"Pola penyelenggaraan diklat yang dikelola bersama-sama antara SMK dengan industri atau asosiasi profesi sebagai institusi pasangan (IP), mulai dari tahap perencanaan, tahap pelaksanaan, sampai tahap evaluasi, serta sertifikasi yang merupakan satu kesatauan program dengan menggunakan berbagai bentuk alternatif pelaksanaan". 
Beberapa pendapat teori diatas dapat dismpimpulkan praktik kerja industri merupakan tahap persiapan yang bertujuan untuk mengembangkan kemampuannya, dan melaksanakan tanggung jawab dalam bidangnya, yang dikelola secara bersamasama oleh SMK dan industri, mulai dari tahap perencanaan, tahap pelaksaan dan sampai tahap evaluasi.

\section{Metode Penelitian}

\section{Tempat Penelitian}

Penelitian ini dilakukan di SMK Negeri 1 Cibinong yang berlokasi di jln. Raya Pemda Karadenan Nomor 07 Cibinong, Kelurahan Karadenan Kecamatan Cibinong Kabupaten Bogor 16913, Provinsi Jawa Barat. Alasan memilih tempat penelitian ini di karenakan SMK Negeri 1 Cibinong merupakan sekolah menengah kejuruan yang terdapat pada kompetensi keahlian teknik gambar bangunan, dan berdasarkan data yang diperoleh, masalah yang akan diteliliti sangat cocok dengan tempat yang telah ditentukan

\section{Waktu Penelitian}

Waktu penelitian ini dilaksanakan selama dua bulan yaitu dari bulan November-Januari 2018 yang teridir dari 3 tahap yaitu tahap persiapan, pelaksanaan, dan pengolahan data. Penelitian ini dilakukan pada waktu tersebut dikarenakan waktu tersebut merupakan waktu yang efektif untuk memperoleh data penelitian.

\section{Metode Penelitian}

Jenis penelitian yang digunakan pada penelitian ini adalah penelitian kuantitatif asosiatif. Metode yang digunakan adalah metode survei dengan desain korelasi. Populasi dalam penelitian ini adalah siswa SMK Negeri 1 Cibinong Kompetensi Keahlian Teknik Gambar Bangunan yaitu sebanyak 212 orang siswa. Sampel dalam penelitian ini menggunakan cluster random sampling, yang akan dilakukan pada siswa kelas XII yaitu sebanyak 69 orang siswa. Untuk siswa dibagi menjadi 2 kelas yaitu 35 siswa kelas XII TGB 1, dan 34 siswa kelas XII TGB 2, dengan jumlah 69 siswa.

\section{Hasil Penelitian dan Pembahasan}

Berdasarkan hasil analisis dan pengujian hipotesis menunjukkan bahwa hipotesis yang diajukan dalam penelitian ini terbukti. Hal ini dapat diartikan bahwa secara umum pada kompetensi keahlian teknik gambar bangunan siswa kelas XII SMK Negeri 1 Cibinong terdapat hubungan antara praktik kerja industri dengan kesiapan kerja siswa.

Populasi penelitian ini berjumlah 212 siswa. Namun untuk responden yang digunakan pada uji coba diambil 15 siswa dari masing-masing kelas dengan total 30 . Maka sampel pada penelitian ini terdiri dari kelas XII TGB 1, sebanyak 35 siswa dan kelas XII TGB 2, 34 siswa dengan total sebanyak 69 siswa. Dari hasil analisis regresi diperoleh persamaan garis regresi $\tilde{y}=$ $92,679+5,171 \mathrm{X}$ dengan $\mathrm{fh}>\mathrm{ft}$ 3,644 > 1,66 dan $r=0,41$. Sehingga jika praktik kerja industri dinaikan sebesar 1 poin maka kesiapan kerja siswa akan naik sebsar 0,41 poin. Kemudian dari hasil analisis korelasi Product Momen menunjukkan bahwa praktik kerja industri mempunyai hubungan yang positif dengan kesiapan kerja siswa. Harga $\mathrm{fh}>\mathrm{ft}$ menunjukkan bahwa praktik kerja industri mempunyai hubungan yang signifikan tehadap kesiapan kerja siswa SMK Negeri 1 Cibinong kompetensi keahlian teknik gambar bangunan. Makna dari hasil analisis regresi dan korelasi tersebut yaitu menunjukkan semakin tinggi praktik kerja industri, maka semakin tinggi pula kesiapan kerjanya. Sehingga terdapat hubungan yang positif antara praktik kerja industri dengan kesiapan kerja siswa SMK Negeri 1Cibinong kompetensi keahlian teknik gambar bangunan. 


\section{Kesimpulan}

Berdasarkan hasil penelitian yaitu terdapat hubungan antara praktik kerja industri dengan kesiapan kerja siswa kelas XII Kompetensi Keahlian Teknik Gambar Bangunan SMK Negeri 1 Cibinong. Nilai koefisien 0,41 dengan kategori tingkat hubungan dan terdapat hubungan yang signifikan dari praktik kerja industri dengan kesiapan kerja siswa. Penelitian dibuktikan nilai $t_{\text {hitung }} \mathrm{g}$ lebih besar $t_{\text {tabel }}$ sebesar 0,41 dengan kategori tingkat hubungan sedang, dan terdapat hubungan yang signifikasikan dari praktik kerja industri dengan kesiapan kerja siswa.

\section{Impilikasi}

Berdasarkan hasil penelitian menunjukkan bahwa terdapat hubungan yang positif dan signifikan antara hubungan praktik kerja industri dengan kesiapan kerja siswa, penelitian ini mengandung implikasi bahwa untuk meningkatkan kesiapan kerja dapat dengan cara meningkatkan atau memperbaharui sistem pelaksanaan praktik kerja industri SMK kompetensi keahlian teknik gambar bangunan. Selain hal tersebut, hasil penelitian ini dapat digunakan di lapangan sebagai dasar dalam menentukan kebijakan-kebijakan di sekolah dengan tujuan meningkatkan kesiapan kerja siwanya dengan melalui praktik kerja industri.

\section{Saran}

Berdasarkan hasil penelitian ini maka peneliti mengajukan beberapa saran sebagai berikut :

\section{Guru dan Sekolah}

Perbaiki proses pembelajaran dan sistem program praktik kerja industri agar lebih efektif, dan sangat penting untuk mengarahkan siswanya untuk lebih meningkatkan keterampilan kerjanya. Keterampilan kerja hendaknya lebih baik lagi dalam melaksanakan praktik kerja industri sehingga memperoleh pengalaman kerja yang bermanfaat ketika peserta didiknya memasuki dunia kerja.

\section{Bagi Siswa}

Berdasarkan kesimpulan siswa diharapkan lebih meningkatkan keterampilan kerjanya ketika melakasanakan praktik kerja industri, sehingga siswa memiliki bekal yang cukup. Praktik kerja industri dapat memberikan peranan yang cukup signifikan terhadap siswa itu sendiri dalam bersaing di dunia kerja dan diharapkan mampu menciptakan peluang kerja sendiri.

\section{Bagi peneliti}

Bagi peniliti selanjutnya, sebaiknya dilakukan lagi penelitian yang serupa dengan cakupan obyek lain yang lebih luas dan variabel lebih dikembangkan lagi karena pada penelitian ini hanya membahas tentang kesiapan kerja siswa.

\section{Daftar Pustaka}

Arikunto, Suharsimi. (2006). Prosedur Penelitian Suatu Pendekatan

Praktek.Jakarta : PT. Rieneka Cipta

Dalyono. (2005). Psikologi Pendidikan.

Jakarta : Rineka Cipta. Dikmenjur.

(2008). Kurikulum SMK.Jakarta :

Dikmenjur.

Dikmenjur. (2008). Pelaksanaan Prakerin. Jakarta : Direktorat Pembinaan Sekolah Menengah

Kejuruan, Depdiknas.

Dikmenjur. (2013). Pedoman Pelaksanaan

Prakerin. Jakarta : Direktorat

Pembinaan Sekolah

Menengah Kejuruan, Depdiknas

Hamalik, Oemar. (2007). Manajemen

Pelatiban

Ketenagakerjaan.Jakarta: Bumi

Aksara

Hamalik, Oemar. (2005). Pengembangan SDM Pelatihan 
Ketenagakerjaan Pendidikan Terpadu.

Jakarta : Bumi Aksara.

Pedoman. (2013). Pelaksanaan Praktik

KerjaIndustri. SMK Negeri 1

Cibinong Prasetyo, Bambang.

(2005). Metode Penelitian

KuantitatifTeoridan Aplikasi.

Jakarta : PT. Raja

GrafindoPersada

Sugihartono. (2000). Aspirasi

SiswaTerhadap Pekerjaan dan

Prestasi Akademik Kaitannya

dengan Kesiapan Memasuki Dunia

Kerjapada Siswa Sekolah Kejuruan

di Daerah Istimewa Yogyakarta.

Laporan Penelitian. FIP : IKIP

Yogyakarta

Undang-Undang RI No. 20 Tahun 2003.

Tentang Pendidikan Nasional.

Jakarta : Depdiknas.

Wibowo. (2011). Manajemen Kinerja.

Jakarta: PT. Raja Grafindo Persada

Wibowo.(2016).Upaya Memperkecil

Kesenjangan Kompetensi Lulusan

Sekolah Menengah Kejuruan

Dengan Tuntutan Dunia

Industri.Yogyakarta:Jurnal

Pendidikan Teknologi dan

Kejuruan Volume 23 Nomor 1

Tabun 2012 
Jurnal Pendidikan Teknik Sipil 